\title{
DETECÇÃO MOLECULAR DO $M$. bovis EM LESÕES TECIDUAIS SUGESTIVAS DE TUBERCULOSE BOVINA
}

\author{
MOLECULAR DETECTION OF $M$. bovis IN TISSUE LESIONS SUGGESTIVE OF \\ BOVINE TUBERCULOSIS
}

\author{
D. A. V. SILVA ${ }^{1}$, M. J. L. SICONELLI ${ }^{2 *}$, K. P. BÜRGER ${ }^{3}$
}

\section{RESUMO}

A tuberculose é uma doença infectocontagiosa de caráter zoonótico de grande importância em saúde pública, portanto, sua identificação e diagnóstico são fundamentais no controle desta enfermidade. Objetivou-se o diagnóstico da tuberculose bovina pelo cultivo microbiológico e detecção molecular do $M$. bovis em lesões teciduais sugestivas de tuberculose bovina. Foram coletadas 50 lesões de bovinos abatidos em dois matadouros-frigoríficos sob SIF na região nordeste do Estado de São Paulo. Foi realizado o cultivo microbiológico em meios de cultura sólidos e a presença do M. bovis foi confirmada pela PCR. A detecção molecular do M. bovis nas lesões sugestivas de tuberculose foi realizada utilizandose a PCR e a nested PCR. Houve crescimento de colônias características de M. bovis em 56\% (28/50) das amostras e $100 \%$ ( 28 amostras) foram confirmadas como M. bovis pela PCR a partir de DNA extraído das colônias. A PCR a partir de DNA extraído das lesões teciduais apresentou 20\% (10/50) das amostras positivas para M. bovis. Entretanto, ao se utilizar a nested PCR, técnica aplicada às amostras negativas na PCR, 18\% (09 amostras) apresentaram bandas amplificadas, sendo consideradas positivas. Assim, o número de amostras positivas quase dobrou (38\% - 19/50). O teste kappa (95\%) mostrou concordância perfeita entre a identificação molecular e o cultivo microbiológico e fraca a sofrível entre o cultivo microbiológico e a detecção molecular do $M$. bovis nas lesões teciduais. Os maiores valores de sensibilidade, especificidade e índice de Youden foram observados na identificação molecular do $M$. bovis nas colônias seguido da deteç̧ão molecular nas lesões teciduais. A detecção molecular do M. bovis em lesões teciduais é possível como alternativa para o diagnóstico rápido da tuberculose bovina, mas não é recomendado e não deve ser utilizado como único método no diagnóstico devido seus baixos valores de sensibilidade, índice de Youden e coeficiente kappa.

PALAVRAS-CHAVE: DOENÇA INFECCIOSA. PCR. ZOONOSE.

AGRADECIMENTOS: Fundação de Amparo à Pesquisa do Estado de São Paulo (FAPESP).

ÁREA TEMÁTICA: Zoonoses. 